\title{
A Unique Project Example Regarding Student Clubs in Higher Education in Turkey
}

\author{
Ilgın, H.Ö. ${ }^{1}$, Ertekin İ. ${ }^{2}$, Yengin, D.A. ${ }^{3}$ \\ ${ }^{1}$ Hicran Özlem ILGIN, Istanbul Aydin University, (Turkey) \\ 2 Irfan ERTEKIN, Istanbul Aydin University, (Turkey) \\ ${ }^{3}$ Didem Ataman YENGIN, Istanbul Aydin University, (Turkey) \\ e-mail: hoilgin@nku.edu.tr
}

\begin{abstract}
The subject of this study is MEMYO Social Solidarity and Aid Club formed by Namık Kemal University Marmaraereğlisi Vocational School Students. The aim of the study is to ensure that the MEMYO Social Solidarity and Aid Club project is an example of a unique project proposal for other higher education institutions. The study consists of a systematic compilation of data on the actualization of 26 aid campaigns conducted by the club during the 2015-2016 Academic Year Spring semester and 2016-2017 Fall semester. The "case analysis" method was used as the research method. For the analysis, the record book used by the club members, the photos taken by the Vocational School Press and Public Relations Unit during club activities, and printed and video news about the national press club work in 2016 were used. As a result of the research, without any formal hierarchical structure, regardless of university student communities, and without limitation to any regulations or rules; it is revealed that the continuity of the activities of the "MEMYO Social Solidarity and Aid Club", which is carried out by the student centre, originated from the original and autonomous study area that the students created. In this context, it is important that the coordinator instructors only assume the role of consultant in the work of the clubs established in higher education, and that a broader movement of the student is provided in terms of club activities and functioning.
\end{abstract}

Keywords: Project, Student, Student Clubs, Higher Education, Social Responsibility

\section{Introduction}

The concept of social responsibility has been built upon the principle of maintaining the activities of the establishment in consideration with the well-being of the society. In other words, social responsibility can be described as both the establishments' liabilities to gain profit and their obligation to respond to the individuals and foundations in the society as well (Sabuncuoğlu, 2004; 66). Social responsibility studies in Turkey are progressing parallel to the development in the world, but they also have important problems in terms of quality and quantity. Social responsibility activities are mainly carried out by civil society organizations and civil society volunteers. In recent years, the number of employees who are involved in corporate social responsibility activities that "companies have realized" is increasing. In some companies, Corporate Volunteering Programs are being developed that are organized by employees' volunteers to make these volunteer activities more systematic and sustainable.

Volunteering, on the one hand, becomes a tool for the society contributions of the individual, while on the other hand it also benefits those who perform these activities. According to researches, volunteers become a happier, more energetic, more hopeful group compared to the communities they are in, and their negative feelings like anxiety, stress, helplessness and hopelessness are decreasing. In addition to these positive outcomes on physical and mental health, individual achievements such as the experiences they experience during the activities performed by the volunteers, the education they receive, the relationships they have established and social networks also have a positive impact on their lives. It is known that voluntary activities, in addition to individual gains, provide positive contributions to social welfare, such as strengthening the resistance of societies, multiplying sharing habits, multiplying their practices, and building a social and cultural infrastructure for faster and decisive partnerships in the solution of social problems. It is also known that as well as individual gains voluntary activities provide positive contributions to social welfare, such as strengthening the 
resistance of societies, multiplying sharing habits, creating a social and cultural infrastructure for faster and more decisive partnerships in the solution of social problems (TOG, 2013; 11-13).

\section{Social Responsibility}

The establishment's approving the existence of the society except its own benefit, being interested in social problems beside its basic responsibilities, considering the results of the actions to be taken in advance constitute the basis of the responsible behavior (Peltekoğlu, 2012; 133).

Whose responsibility is social responsibility? This responsibility belongs to the whole community and the administration. That is, it should aim at not developing or presenting a brand but providing benefit to a social problem. Increasing social responsibility activities of the corporations and especially private sector has caused some contradiction in terms. Activities such as advertisement and sponsorship which are within the other area of activity of the private sector are confused with the social responsibility campaigns. Social responsibility does not only belong to private corporations. Government agencies and non-governmental organizations should have obligations and studies on this subject

(http://www.sabah.com.tr/yazarlar/cumartesi/bsemerci/2008/08/02/sosyal_sorumluluk_bilinciDate of Access).

Social responsibility is a concept that public, private sector and non-governmental organizations come together around a goal and head for a common life. From another point of view, social responsibility is the fact that individuals and corporations follow the actions which develop and protect not only their own benefits but also the general benefits of the society(http://www.sosyalsorumluluk.org/sosyalsorumluluk-nedir/Date of Access 08.01.2017)

\subsection{Students Clubs In High Education In Turkey}

Vocational Schools in Higher Education in Turkey have a wide and important place. When completing the vocational training of the students; Communities for the preparation of social coexistence and the acquisition of life awareness at the same time; In other words student clubs; It provides an appropriate application area for the individual gains that need to be assessed in educational life. With a brief description, "Student Club" is a group formed by bringing students together in order to realize educational, health, sports, social, science and cultural activities according to the "Student Club Direction" in a planned and organized manner (YBÜ, 2017).

The student communities in the Universities of Turkey meet under three headings as Scientific Qualified Societies, Culturally Qualified Societies, Sports Qualified Societies. Emergency and First Aid Group, AR-GE Innovation Community, Plant Protection Society, Biomedical Technologies Research and Development Group, Industrial Engineering Group, Philosophy Group, Theme Group, Social Solidarity Group are some examples of these communities (NKU, 2017a). The activities of the clubs bring benefits to the universities at the point of introducing the universities to other world countries on national and international platforms, and at the same time they transform the leisure activities of the students in a quality way.

The student clubs, in other words student communities, operate according to the principles laid down in the Regulation laid down by the Higher Education Institution. With the Law No. 2547 on Higher Education, the boundaries of clubs, establishments of clubs, organizational forms of clubs, club hierarchies and even closure principles of the student clubs are explained in TR Official Gazette (1984). These regulations are applied in various forms accepted by university senates (NKU, 2017b).

As mentioned above, Social Solidarity Clubs, one of the communities operating in different fields, constitute the subject of this work. In this context, MEMYO Social Solidarity and Aid Club, one of the Social Solidarity Clubs working voluntarily, is considered as a unique example project in this study. The work of the club is unique because the working principles are not specified by regulations or framework provisions. In addition, the work of the club is unique because there is no formal boundaries and hierarchical organization of the club, which is basically voluntary. And also the social solidarity work that the club is doing without any academic record is unique and the continuity of these social activities has been achieved. In this context, this study consists of a systematic compilation of 
data on the realization of 26 aid campaigns carried out by students of Marmara Region Vocational School of Namık Kemal University during the academic term of 2015-2016 academic year and fall semester of 2016-2017 which means one year period

\subsection{Materials and Methods}

In this study, as the Social Solidarity and Solidarity Club of the Vocational School students, the activities of the club members will be examined in order to evaluate the activity areas. The data will be compiled with observations carried out over a year as consultant teaching staff. In this context, this study carries a qualitative research feature in the context of a "situation analysis".

A case study is a summary of an event, event, or problem that involves a reality or a hypothetical situation, and includes the complexities encountered in its environment (UNSW, 2016). Analyzing a case study requires experimenting with applying knowledge and thinking skills to a real situation. To learn from a situational analysis, it is necessary to "analyze the information, apply the information, rationalize and draw conclusions" (Kardos and Smith, 1979; 1). The case study is seen as a distinctive approach in which one or more events, media, programs, social groups, or other interrelated systems used in the search for answers to scientific questions are examined in depth (McMillan, 2000; 91). The case study is also described as a research method in which a current phenomenon operates in its own reality and when there is more than one data source (Yin, 2002; 59).

The study consists of a systematic compilation of data on the realization of 26 aid campaigns conducted by the club during the 2015-2016 Academic Year Spring semester and 2016-2017 Fall semester. The "situation analysis" method was used as the research method. For the analysis, the records used by the club members, the photographs taken by the School Press and Public Relations Unit during club activities, and the printed and video news at the national press in 2016 were used.

\section{Case and Findings}

The Social Solidarity and Solidarity Club of Marmara Region have started its activities on December 2015 with a proposal by a volunteer student. The student has suggested to the class that the stationery materials requested for 32 students in Bitlis Güzelsu Primary School in www.kardesokullari.com will be supplied with a campaign and sent to this school. Instructor of the course in which the recommendation was made has since served as a consultant in club activities since that date. The volunteer students made a list of the requested materials that could not be completed on the demand list and made a supply chain by informing the students who wanted to participate in the campaign that the incomplete material names and figures. The student who requested the start of the campaign completed the required stationery materials and more in the same week by taking the permission of the management and placing a table and chair in the entry area of the school and exhibiting the materials at the table and raising the number of students participating in the campaign rapidly within one week.

\subsection{Organization Scheme of the Club}

The student who made the first proposal started to be referred to as "club president" by the students without any election. The members of the club, who have accepted to be a club member without any formal registration, have defined themselves as "MEMYO Social Solidarity and Aid Club Member". To the core team who is consisting of approximately ten students and closely following the club's activities, close friends of team members, roommates, friends of hostels or dormitories have been added as another ring. While these members followed their activities through their friends, they also directed their own circles to supply the missing items in the campaigns. At this point, the necessary materials were procured from the county shopkeepers and new participants were added to the group. And in this context, more aid material was collected than the materials needed for the campaigns. On the other hand, with the acceleration of the studies with the beginning of the 20162017 academic year, with the news shared by the club's social media account, the college's own graduate students began to support the club as well. So, the club started to get materials from outside the Marmaraeregli region. In this context, it should be stated that it is inevitable to establish a graduate platform for the students who have graduated from the Vocational School of Marmaraereğlisi to communicate with their school again and give support to the works done from outside. 
The organizational chart of a club without being bound to rules or regulations in an informal and organic way is in the format indicated below. In this organization chart where each ring is interacting and the exchange of ideas takes place; each unit and club counsellor, in other words, the instructor of the counsellor, is located outside the chart as an environmental unit.

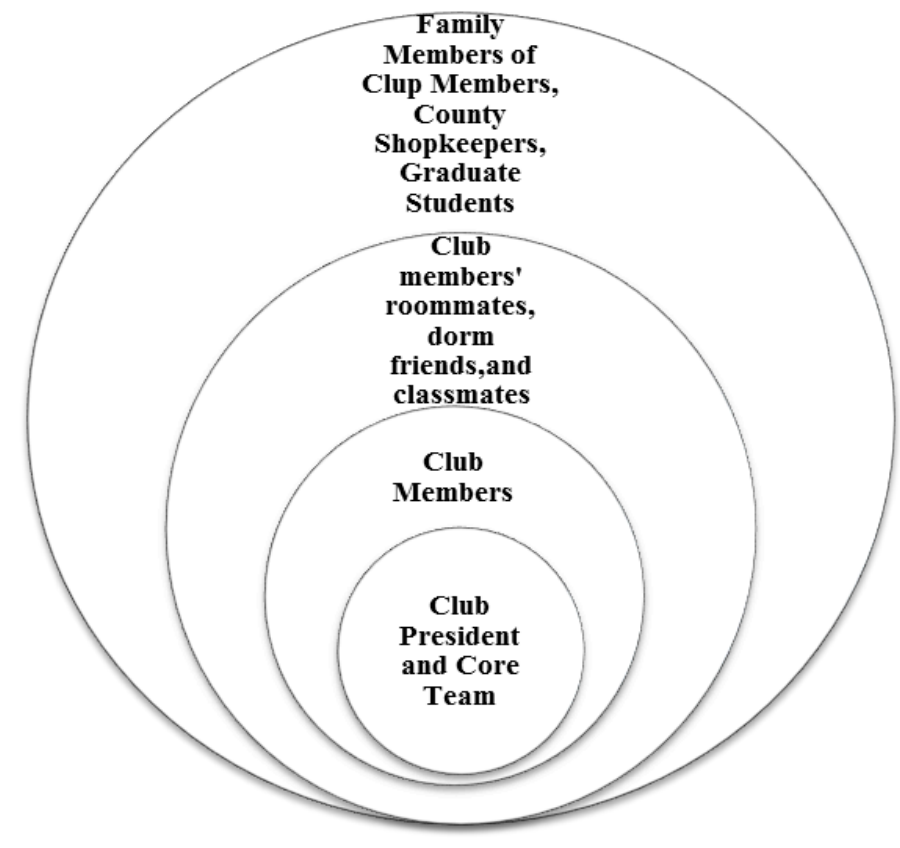

Figure 1. MEMYO Social Solidarity and Aid Club Organization Scheme

\subsection{Continuity of Campaigns}

The first campaign was completed quickly and necessary materials were collected. With the conclusion that the required material has been collected, the new school proposal has begun to come by the students. In this context, campaign continuity has become a "culture" in a practical way in the period when the club is still in the era when it was still establishing. The students have been working periodically for both schools at the same time. Ardahan Şehit Şenay IIlan Primary School and Şırnak Elcani Primary School, Adıyaman Besni Kızılkaya Village Primary School and Muş Gazeteciler Cemiyeti Book Campaign can also be given as an example of campaigns that takes place at the same time. On the other hand, the involvement of the clubs at the local and national press caused students to accelerate their work and encourage them in their work.

\subsection{MEMYO Social Solidarity and Aid Club at National Press}

The involvement of the club in national and local press has contributed to the acceleration of the studies. On the other hand, it has been observed that placing the club at the top by the students and other club volunteers involved in the club's work gives an impetus to the efficiency of the work. Because of this, under this heading included news at the national press, and the returns of this news was addressed.

The fact that club activities were included in the Hürriyet Journal with a title "Started with one School, reached at Three Schools " on 08 January 2016 attracted interest among the club members as well as the students who supported the campaign and the students who were abstaining to support the campaign (Hürriyet, 2016). The news was featured on all announcement boards of the school. It has been observed that students are excited by the fact that they see their photographs in newspaper news. 
The news "Assistance from Marmaraereğlisi to Çukurca" which appeared at local and national press took place in the notice boards of the school (Haber Marmara 2016). On the other hand, the aids sent to the students who survived in the fire of Adana Aladağ Dormitory were included in the news with the headline "Adana Aladağ'a Yardım Eli" (Habertürk, 2016). The fact that the news takes place at the national level and that students see themselves and their close friends in newspaper news have increased the interest in the campaigns rapidly. On the other hand, it was observed during the work that these news increased the interest of students to the club.

News in the national and local media were followed up by the İhlas News Agency and turned into video news by the title boot campaign for the Nusaybin Balaban Elementary School. The news, which included interviews with students, and the news that the students packed the campaign materials, took place in the media. The video news, shared with the title "They sent boots to their brothers at East for them to not feel the cold ", was shared in social media accounts of the students, helping to reach a wider audience for the club (Mynet, 2016). The students participating in the video news had the opportunity to share their voices to their families, friends and relatives, to announce the success of a social assistance project they were involved with and the importance of social sensitivity.

\subsection{The club's 2016 Year of Studies}

In order to systematically view the activities of the club, the studies are shown in the tables below. The tables are prepared in two sections; 2015-2016 Academic Year Spring Semester and 2016-2017 Academic Year Fall Semester. On these charts, the material supplied, the number of students prepared the campaigns, the duration of the campaign, the numbers of active students participating in the campaign are given and these data were taken from the registry of the common use of the club. In the registry book there are also copies of the cargo notes of the packages sent. Students of the Social Solidarity and Aid Club can review the notebook at any time they wish, and they can express their ideas if they wish. The notebook was kept under the supervision of the instructor by the request of the students.

The figures of the students participating in the campaign mentioned below were determined by examining the photographs taken during the campaigns and the photographs taken during the packaging processes especially on the days when the campaign packages were sent. In addition to the core team performing the activities of the club, it was also determined from photographs that there were changes between the other students periodically.

Table 1. The Campaigns at 2015-2016 Academic Year Spring Semester

\begin{tabular}{llccc}
\hline $\begin{array}{l}\text { The Name of } \\
\text { School }\end{array}$ & Supplied Material & $\begin{array}{l}\text { How Many } \\
\text { Students } \\
\text { Benefited }\end{array}$ & $\begin{array}{l}\text { Campaign } \\
\text { Time }\end{array}$ & $\begin{array}{l}\text { Number of Active } \\
\text { Students Attending } \\
\text { The Campaign }\end{array}$ \\
\hline $\begin{array}{l}\text { Bitlis Güzelsu } \\
\text { Elementary School }\end{array}$ & Stationery & 32 & 1 Week & 35 \\
\hline $\begin{array}{l}\text { Ardahan Şehit } \\
\text { Şenay İlan } \\
\text { Elementary School }\end{array}$ & $\begin{array}{l}\text { Stationery, activities } \\
\text { and sports equipment, } \\
\text { musical instruments }\end{array}$ & 35 & 2 Week & 45 \\
\hline $\begin{array}{l}\text { Şırnak Elcani } \\
\text { Stationery }\end{array}$ & 20 & 1 Week & 40 \\
\hline
\end{tabular}




\begin{tabular}{llccc}
\hline \multicolumn{2}{l}{ Elementary School } & & & \\
\hline $\begin{array}{l}\text { Bitlis Çukurca } \\
\text { Elementary School }\end{array}$ & Boot & 28 & 2 Week & 25 \\
\hline $\begin{array}{l}\text { Nusaybin Balaban } \\
\text { Elementary School }\end{array}$ & Boot & 36 & 1 Week & 35 \\
\hline $\begin{array}{l}\text { Adıyaman Besni } \\
\text { Kizılkaya Köyü } \\
\text { Elementary School }\end{array}$ & Stationery & 20 & 1 Week & 30 \\
\hline $\begin{array}{l}\text { Muş Journalists } \\
\text { Association }\end{array}$ & Book & 30 & 1 Week & 30 \\
\hline
\end{tabular}

In order to systematically view the activities of the club, the studies are shown in the tables below. The tables are prepared in two sections; 2015-2016 Academic Year Spring Semester and 2016-2017 Academic Year Fall Semester. On these charts, the material supplied, the number of students prepared the campaigns, the duration of the campaign, the numbers of active students participating in the campaign are given and these data were taken from the registry of the common use of the club. In the registry book there are also copies of the cargo notes of the packages sent. Students of the Social Solidarity and Aid Club can review the notebook at any time they wish, and they can express their ideas if they wish. The notebook was kept under the supervision of the instructor by the request of the students.

The figures of the students participating in the campaign mentioned below were determined by examining the photographs taken during the campaigns and the photographs taken during the packaging processes especially on the days when the campaign packages were sent. In addition to the core team performing the activities of the club, it was also determined from photographs that there were changes between the other students periodically.

In the study of 2015-2016 academic year fall period mentioned in Table 1; Ardahan Şehit Şenay It took some time to procure the musical instruments and intelligence sets demanded for the Ad Primary School and for this reason the studies took 2 weeks. For the campaign done for Bitlis Çukurca Elementary School, because it was first boot campaign of the clup, the number and sex appropriate procurement process took time, so it took 2 weeks to complete the campaign. After this campaign, all packages sent were sent on behalf of the students names. After the Nusaybin Balaban Elementary School Campaign, letters which written by the students of the Vocational School, were put at the all of the packages prepared by the club members. Second hand books supplied by the students were sent to Mus in order to support the book campaign organized by Mus Journalists Association for the village schools.

Due to the fact that no special packaging was made for the individuals during the campaigns made during the first period, the collected materials were sent packed. Shared photos are photos taken just before and after the packages are completed by participation of all students participating in club activities. In this context, students discovered a new way of communication by writing letters to the students they had never known. On the other hand they have seized a new opportunity to express their feelings. In this context, letter writing culture has been remembered. On the other hand, letters from a single pen were written by forming a common idea with 10-20 people. At the same time, this study allowed the student to experience teamwork.

The table below is showing the studies at 2016-2017 Fall semester. As can be seen from the table, while the number of studies in the spring semester of the 2015-2016 academic year was 7, the number of studies in the autumn semester 2016-2017 academic year increased to 19 . The main 
reason for this is the development of the social responsibility consciousness in students and direct communication of the different schools which are informed about the studies of the club. Another village school teacher, who is close to a village school that is being helped during the spring semester, can be given as an example. He communicated with the club president and he reported their needs without a mediator. In addition, the increased number of studies can be explained by the increase in the number of materials that came via the social media.

Table 2. 2016-2017 Academic Year Fall Semester Studies

\begin{tabular}{|c|c|c|c|c|}
\hline The Name of School & $\begin{array}{l}\text { Supplied } \\
\text { Material }\end{array}$ & $\begin{array}{l}\text { How Many } \\
\text { Students } \\
\text { Benefited }\end{array}$ & $\begin{array}{l}\text { Campaign } \\
\text { Time }\end{array}$ & $\begin{array}{l}\text { Number of } \\
\text { Active Students } \\
\text { Attending The } \\
\text { Campaign }\end{array}$ \\
\hline $\begin{array}{l}\text { Van Tuşba Mustafa Kemal } \\
\text { Atatürk Elementary School }\end{array}$ & Stationery & 25 & 1 Week & 10 \\
\hline $\begin{array}{l}\text { Ağrı Patnos Kazanbey Middle } \\
\text { School }\end{array}$ & Boot & 63 & 2 Week & 45 \\
\hline $\begin{array}{l}\text { Van Başkale Ömerdağı } \\
\text { Elementary School }\end{array}$ & Boot & 25 & 1 Week & 45 \\
\hline $\begin{array}{l}\text { Mardin Savur İçören } \\
\text { Elementary School }\end{array}$ & $\begin{array}{l}\text { Snoozies, coats, } \\
\text { boots, socks, toys }\end{array}$ & 10 & 2-3 Days & 25 \\
\hline $\begin{array}{l}\text { Ağrı Eleşkırt Gökçayır Köyü } \\
\text { Elementary School }\end{array}$ & Stationery & 18 & 2-3 Days & 40 \\
\hline $\begin{array}{l}\text { Suruç Yörecik Elementary } \\
\text { School }\end{array}$ & Stationery & 10 & 2-3 Days & 25 \\
\hline $\begin{array}{l}\text { Şırnak Cizre Düzova } \\
\text { Elementary School }\end{array}$ & Boot and coats & 16 & 1 Week & 45 \\
\hline $\begin{array}{l}\text { Siirt Şirvan Damlıköyü } \\
\text { Elementary School }\end{array}$ & $\begin{array}{l}\text { Stationery and } \\
\text { Book }\end{array}$ & 13 & 1 Week & 35 \\
\hline $\begin{array}{l}\text { Bitlis Güroymak Saklı Village } \\
\text { Elementary School }\end{array}$ & $\begin{array}{l}\text { Scarf, beret and } \\
\text { coat }\end{array}$ & 13 & 1 Week & 45 \\
\hline $\begin{array}{l}\text { Adana Aladağ Atatürk } \\
\text { Elementary School }\end{array}$ & $\begin{array}{l}\text { Boot, socks and } \\
\text { stationery }\end{array}$ & 12 & 1 Day & 55 \\
\hline $\begin{array}{l}\text { Urfa Mehmet Akif Ersoy } \\
\text { Middle School }\end{array}$ & Boot and socks & 14 & 3 Days & 25 \\
\hline $\begin{array}{l}\text { Mardin Midyat Ortaca Village } \\
\text { Elementary School }\end{array}$ & Stationery & 22 & 1 Day & 35 \\
\hline $\begin{array}{l}\text { Ağrı Patnos } 14 \text { Nisan } \\
\text { Elementary School }\end{array}$ & Stationery & 19 & 3 Days & 35 \\
\hline $\begin{array}{l}\text { Mardin Dargeçit Altınoluk } \\
\text { Elementary School }\end{array}$ & Scarf and beret & 10 & 2 Days & 20 \\
\hline Mardin Savur Başağaç & Boot & 22 & 1 Week & 45 \\
\hline
\end{tabular}




\begin{tabular}{|c|c|c|c|c|}
\hline Elementary School & & & & \\
\hline Hakkari Çukurca Ormanlı & Boot and & 25 & 1 Week & 35 \\
\hline Elementary School & Stationery & & & \\
\hline $\begin{array}{l}\text { Van Başkale Sağmallı Village } \\
\text { Elementary School }\end{array}$ & $\begin{array}{l}\text { Boots, coats, } \\
\text { stationery, berets, } \\
\text { gloves and socks }\end{array}$ & 42 & 1 Week & 55 \\
\hline $\begin{array}{l}\text { Batman Kozluk Ulucanlar } \\
\text { Elementary School }\end{array}$ & $\begin{array}{l}\text { Boot, coats, } \\
\text { stationery }\end{array}$ & 25 & 1 Week & 40 \\
\hline $\begin{array}{l}\text { Bitlis Mutki Güvenli } \\
\text { Elementary School }\end{array}$ & $\begin{array}{l}\text { Boots, coats, } \\
\text { scarves, berets, } \\
\text { socks, gloves, } \\
\text { stationery and } \\
\text { books }\end{array}$ & 30 & 1 Week & 45 \\
\hline
\end{tabular}

The aid to Adana Aladağ Atatürk Elementary School mentioned in Table 2 are packages prepared for students who survived in a burning dormitory (Anadolu Agency, 2016). The package was prepared and packed by club members without losing time in the morning of the fire night. At the package, the letter written by the club members was included. This study was planned by students in an evening. Necessary researches have been done and as soon as the information of the students and the school learned the aid was sent. This campaign has also taken place widely in the national and local media (Milliyet, 2016).

With the aid organization of Mardin Savur Başağaç Elementary School, mentioned in Table 2, a new package added to the aid packages and these packages named "teacher's package". Teacher's names were written to these packages. "Teacher's package" includes stationery material, atlas, Turkish Dictionary, Turkish Spelling Book, appropriate reading books for class, etc. The idea of preparing teacher's package has been proposed and accepted by a member of the club who is in contact with one of the teachers. Later, it was continued as a club culture in other studies. Another work in this table should be stated again Van Başkale Sağmallı Village Primary School for the work done. The interaction with the club was met with enthusiasm by the students that the teacher was graduated from Namık Kemal University. And the number of volunteer employees of the campaign increased.

Within one year, the club sent aids to the 25 schools and one association (Muş Journalists Association). The total number of students reached by the club is 628 .

\subsection{Limitations of Club Works}

Limitations of club work will be handled under the headings, Limitations on work, limitations on political views, limitations of information on trustee and limitations on delivery of the package.

The fact that there are no specific rules or regulations of club operations prevents the loss of time by providing freedom of movement and bureaucratic procedures; but disruptions in information flows, the fact that students do not know each other very well conluded the work has brought to the point of stopping. The counseling instructor took measures to remove communication barriers and the works resumed again. Because club members are composed of students from different departments and classes; club functioning that converges around the same goal but faces problems due to differences in opinions; systematized by seing the consultant as an authority by the students. It is possible to say that freedom of not being bound by any rule turned out to be a disadvantage in the point of view of different cultures, ethnic identities and views. It is possible to say that the freedom of 
being free from any rule at the point of expression of the ideas turned out to be a disadvantage in the point of view of different culture, ethnic identity and opinion.

Most of the campaigns were done with the messages of the teachers who left a message to the site of "www.kardesokullari.com". In this context, phone connection was done with people leaving messages on the site and it is learned what the needs are and how many students are in need. Schools that leave a message on this website formed set of target schools. As a natural consequence of Turkey's geographical and climatic conditions, more calls for help from schools in the east and southeast of Turkey are included in this website. As a result, the schools where the aid work has been done have become concentrated in a certain part of the country. The presence of ethnic differences in the east of Turkey has been criticized by the students who have a nationalist perspective. These criticisms have reached the level of reaction from time to time. Students who responded to the fact that the aid packages were being sent to the eastern parts of the country expressed their reaction from time to time to the club president, core club members and advisors. These students were told that the purpose of the club was "to meet the needs of the children and that the club did not carry any political identity". It was observed that these students also participated in the studies at different times.

Limitations on accuracy and validity of information; It was necessary to carry out a research on whether the persons leaving the message on the site were employees of the school that was the victim. The phone numbers given were searched by the club president. Also, the authenticity and validity of the information is confirmed by the schools' websites. When necessary, the village headman was called by phone and the information were tried to confirm.

Since the packages sent were sent to village schools in Southeast and Eastern Anatolia, some difficulties were encountered. Due to the lack of an effective distribution network of the cargo companies in the region, the packages were sent by PTT cargo working to all regions. On the other hand, due to terrorist operations in the region and measures against terrorist attacks, packages arrived late to the schools. In this context, the fact that the club president followed packages and carried out follow-up calls to PTT branches benefited minimizing the limitations.

\section{Discussion and Conclusion}

University management and academicians should see volunteerism and community activities as a learning opportunity; establishment of the necessary institutional infrastructure and financial resources for these activities; students should not engage in bureaucratic obstacles as much as possible while conducting these studies; sharing good practices as good examples; to be awarded through public appreciation is critical for the development of such activities. There should not be an academic consulting position that monitors, supervises and approves community work. The role of academics should be limited only to providing the expertise required by the students in the areas they are engaged in, as well as the expertise demanded by them (TOG, 2013).

When the findings obtained from this study are compiled; student activities should be supported in the direction of social benefit by the university administrations; should be dealt with in the development of the social responsibility consciousness at the point of acquiring social sensitivity and the way of expressing themselves in social life besides vocational education of the students. The educational environment has a key role to the creation of a sustainable social responsibility consciousness. In this context, students should be supported by management and academicians, students should be provided with autonomous areas where they can conduct their activities, and instructors should assume the role of consultant, not manager. 


\section{References}

[1] Anadolu Agency (2016).Adana'da özel öğrenci yurdunda yangın: 12 kişi hayatını kaybetti.

Retrieved from:http://aa.com.tr/tr/gunun-basliklari/adanada-ozel-ogrenci-yurdunda-yangin-12kisi-hayatini-kaybetti/695777.Access Date: 02.01.2017.

[2] Haber 3 (2016). Marmara Ereğlisi'nden Güneydoğu'ya Yardım Eli. Retrieved from:http://www.haber3.com/marmara-ereglisinden-guneydoguya-yardim-eli3901692h.htm.Access Date: 10.01.2017.

[3] Haber Marmara (2016). Marmaraereğlisi'nden Çukurca'ya Yardım Eli. Retrieved from: http://www.habermarmara.com.tr/haber/22618/duzeltme-marmara-ereglisi-nden-cukurca-yayardim-eli/.Access Date: 22.11.2016]

[4] Habertürk (2016).MEMYO'dan Aladağ'a Yardım Eli. Retrieved from: http://www.haberturk.com/yerel-haberler/haber/50171254-memyodan-aladaga-yardim-eli Access Date: 03.01.2017.

[5] Hürriyet (2016).Bir Okulla Başlandı Üç Okula Ulaşııdı. Retrieved from: http://www.hurriyet.com.tr/bir-okulla-baslandi-uc-okula-ulasildi-37224344.Access Date: 01.12 .2016$.

[6] Kardos, G. \& Smith, C.O. (1979). On writing engineering cases. Proceedings of the American Society for Engineering Education National Conference on Engineering Case Studies, Ottawa, Ontario, Canada.

[7] McMillan, J. H. (2000). Educational Research: Fundamentals for the Consumer (4th ed.). New York: Addison Wesley Longman, Inc.

[8] Milliyet (2016). Memyo'dan Aladağ'a Yardımeli. Retrieved from:http://www.milliyet.com.tr/memyo-dan-aladag-a-yardim-eli-tekirdag-yerelhaber1729505/.Access Date: 10.01.2017.

[9] Mynet (2016). Doğudaki Kardeşleri Üşümesin Diye Bot Gönderdiler. Retrieved from: http://www.mynet.com/tv/dogudaki-kardesleri-usumesin-diye-bot-gonderdiler-vid3987663/.Access Date: 25.12.2016.

[10] NKU (Namık Kemal University) (2017a). NKU Toplulukları. Retrieved from: http://topluluklar.nku.edu.tr/topluluktipi_sayfa/0/s/9326/13224.Access Date: 04.05.2017).

[11] NKU (Namık Kemal University) (2017b). Yönergeler. Retrieved from: http://topluluklar.nku.edu.tr/yonerge/0/s/9323/13178.Access Date: 04.05.2017

[12] TOG (Community Volunteers Foundation / Toplum Gönüllüleri Vakfı)2013. Üniversitelerde Sosyal Sorumluluk ve Sosyal Girişimcilik Pilot Projesi, Proje Raporu, İstanbul.

[13] TR Official Gazette (Türkiye Cumhuriyeti Resmi Gazetesi). Yükseköğretim Kurumlari, MedikoSosyal Sağlik, Kültür Ve Spor Işleri Dairesi UygulamaYönetmeliği.Date of Official Gazette: 03.02.1984 Number of Official Gazette: 18301.

[14] UNSW (2016).What is a Case Study? Retrieved from: https://student.unsw.edu.au/what-casestudy. Access Date: 03.11.2016.

[15] YBÜ (Ankara Yıldırım Beyazıt University) (2017). Retrieved from: https://ybu.edu.tr/sks/contents/files.Access Date: 04.05.2017.

[16] Yin, R.K. (2002).Case study research: Desing and methods. California: Sage Publications Inc.

[17] Sabuncuoğlu, Z. (2004). İşletmelerde Halkla İlişkiler, Bursa, Aktüel Publishing. 